\title{
Uji Efektivitas Ekstrak Etanol Buah Naga Putih (Hylocereus undatus) terhadap Penurunan Kadar Asam Urat Darah pada Mencit (Mus musculus)
}

\author{
(The Effectiveness of Ethanol Extract of White Dragon \\ Fruit (Hylocereus undatus) on the Reduction of Blood Uric \\ Acid Levels in Mice (Mus musculus))
}

MELLOVA AMIR*, JULIANA IREM ADRIANA PURUKAN

Program Studi Farmasi, Fakultas Farmasi, Institut Sains dan Teknologi Nasional

Jl. Moh. Kahfi II, Srengseng Sawah, Jagakarsa, Jakarta Selatan

Diterima 5 Juli 2018, Disetujui 29 Agustus 2018

\begin{abstract}
Abstrak: Buah naga putih (Hylocereus undatus) mengandung flavonoid yang dapat menghambat kerja enzim xantin oksidase yang dapat mengurangi kadar asam urat. Penelitian bertujuan untuk mengetahui efektivitas ekstrak etanol buah naga putih dalam menurunkan kadar asam urat darah pada mencit yang diinduksi kafein secara oral dengan dosis $15,6 \mathrm{mg} / \mathrm{kgBB}$. Sampel buah naga putih diambil saat berumur 50-55 hari setelah muncul bunga. Pada uji efektivitas, hewan coba mencit dibagi menjadi lima kelompok perlakuan dan diinduksi dengan kafein yaitu kelompok kontrol negatif yang hanya diinduksi kafein, kelompok kontrol positif diberikan allopurinol 10,4 mg/kgBB, kelompok dosis 18,2 $\mathrm{mg} / \mathrm{kgBB}$, kelompok dosis $36,4 \mathrm{mg} / \mathrm{kgBB}$, kelompok dosis $72,8 \mathrm{mg} / \mathrm{kgBB}$ ekstrak etanol buah naga putih. Pengukuran kadar asam urat darah dilakukan sebelum induksi (hari ke 1), sesudah induksi atau sebelum pemberian ekstrak (hari ke 6) dan sesudah pemberian ekstrak pada (hari ke 9, 12 dan 15). Hasil penelitian menunjukkan bahwa ekstrak etanol buah naga putih dosis $72,8 \mathrm{mg} / \mathrm{kgBB}$ dapat menurunkan kadar asam urat darah pada mencit secara bermakna dibandingkan dengan dosis $18,2 \mathrm{mg} / \mathrm{kgBB}$ dan dosis $36,4 \mathrm{mg} / \mathrm{kgBB}$, tetapi tidak berbeda bermakna dengan kontrol positif (allopurinol) dengan presentase penurunan sebesar $92,16 \%$.
\end{abstract}

Kata kunci: Ekstrak buah naga putih, asam urat darah, kafein, allopurinol.

\begin{abstract}
White dragon fruit (Hylocereus undatus) contains flavonoids that can inhibit the action of xanthine oxidase enzymes that can reduce uric acid levels. The aim of this research is to know the effectiveness of white dragon ethanol extract in decreasing uric acid level in caffeine-induced mice with dose $15.6 \mathrm{mg} / \mathrm{kgBW}$ (body weight). White dragon fruit samples taken at the age of 50-55 days after the flower appeared. In the effectiveness test, animals were divided into five groups of treatments and induced by caffeine i.e. negatively control group induced only by caffeine, positive control group given allopurinol $10.4 \mathrm{mg} / \mathrm{kgBW}$, group of dose $18.2 \mathrm{mg} / \mathrm{kgBW}$, group of dose $36.4 \mathrm{mg} / \mathrm{kgBW}$, group of dose $72.8 \mathrm{mg} / \mathrm{kgBW}$ ethanol extract of white dragon fruit. Measurements of blood uric acid levels were performed before induction (day 1), after induction or before administration of the extract (day 6) and after administration of the extract on (days 9,12 and 15). The results showed that ethanol extract of white dragon fruit dose $72.8 \mathrm{mg} / \mathrm{kgBW}$ could significantly lower blood uric acid levels in mice compared to dose $18.2 \mathrm{mg} / \mathrm{kgBW}$ and dose $36.4 \mathrm{mg} / \mathrm{kgBW}$, but not significantly different with positive control (allopurinol) with percentage decrease of $92.16 \%$.
\end{abstract}

Keywords: White dragon fruit extract, blood uric acid, caffeine, allopurinol.

\footnotetext{
* Penulis korespondensi, Hp. 082125779916

e-mail mellova.masrizal@gmail.com:
} 


\section{PENDAHULUAN}

PERKEMBANGAN zaman dan globalisasi telah membawa banyak perubahan terhadap gaya hidup dan kebiasaan makan yang tidak sehat di masyarakat ${ }^{(1)}$ yang dapat menimbulkan berbagai penyakit degeneratif diantaranya adalah gangguan asam urat atau gout. Produksi asam urat yang berlebihan dan berkurangnya ekskresi asam urat melalui ginjal, serta gabungan dari dua gejala tersebut dapat menimbulkan penyakit gout $^{(2,3)}$.

Peningkatan kadar asam urat dalam darah diatas batas normal (hiperurisemia) dapat terjadi pada kondisi patologis, dimana pada wanita di atas $6 \mathrm{mg} / \mathrm{dL}$ dan pada pria di atas $7 \mathrm{mg} / \mathrm{dL}$. Nilai asam urat normal pada wanita adalah 2,4-6,0 $\mathrm{mg} / \mathrm{dL}$ dan pria 3,0-7,0 mg/dL ${ }^{(4,5)}$. Menurut hasil Riskesdas 2012 prevalensi penyakit sendi Indonesia adalah $11,9 \%{ }^{(6)}$.

Studi epidemiologi menunjukan bahwa pasien dengan hiperurisemia sering memiliki kelainan sindrom metabolik diantaranya resistensi insulin, obesitas dan hiperlipidemia ${ }^{(7)}$. Adanya sindrom metabolik pada pasien dengan hiperurisemia harus dikontrol komponennya seperti obesitas, tekanan darah tinggi dan lainnya sehingga mengurangi risiko penyakit kardiovaskular ${ }^{(8)}$. Studi menunjukan bahwa gout dihubungkan dengan resiko kematian yang tinggi pada semua kasus dari semua penyebab dan penyakit $\operatorname{kardiovaskular}^{(7)}$

Berbagai usaha dapat dilakukan untuk mengobati penyakit asam urat, diantaranya dengan mengonsumsi obat-obatan. Kelompok obat yang dapat digunakan untuk terapi penyakit gout yaitu obat yang mempengaruhi kadar asam urat (urikostatik) atau obat yang menghentikan proses inflamasi (urikosurik) akut. Obat golongan urikostatik diantaranya allopurinol yang bekerja menghambat kerja enzim xantin oksidase yang mengubah hipoxantin menjadi xantin, dan berikutnya mengubah xantin menjadi asam urat ${ }^{(9)}$.

Allopurinol didalam tubuh mengalami metabolisme menjadi oksipurinol (alozantin) yang juga bekerja sebagai penghambat enzim xantin oksidase dan mengurangi produksi asam urat tanpa mengganggu biosintesa purin ${ }^{(9)}$. Manajemen obat untuk menurunkan kadar asam urat harus diperhitungkan dengan tepat, karena dengan pemberian allopurinol dapat menimbulkan efek samping berupa hipersensitivitas allopurinol sindrom (AHS), diantaranya reaksi nyeri kepala, alergi kulit dan lainnya ${ }^{(10)}$.

Obat tradisional sebagai obat alternatif banyak dikembangkan untuk pengobatan berbagai penyakit, sebagai upaya menghindari efek samping yang ditimbulkan oleh obat kimia. Banyak obat alam yang secara empiris telah terbukti aman digunakan dalam jangka panjang, sehingga perlu banyak studi agar dapat dikembangkan menjadi obat nutrasetikal.

Tanaman jenis kaktus merupakan salah satu tanaman yang dapat digunakan sebagai obat. Buah naga (Dragon fruits) adalah salah satu jenis kaktus yang dikenal di Indonesia ${ }^{(9)}$. Buah naga merah mempunyai aktifitas antioksidan lebih tinggi dibandingkan dengan buah naga putih ${ }^{(11,12)}$, mengandung vitamin $\mathrm{C}$ dan likopen yang dapat menurunkan resiko kanker dan penyakit jantung ${ }^{(13)}$.

Buah naga sudah banyak yang dibudidayakan diantaranya buah naga berdaging buah bewarna putih (Hylocereus undatus), bewarna merah (Hylocereus polyhisus), bewarna super merah (Hylocereus costaricensis) dan buah naga berkulit kuning dengan warna daging buah putih (Selenycerens megulanthus ${ }^{(14)}$. Tumbuhan buah naga daging putih (Hylocereus undatus (Haw.) Britton \& Rose) mengandung senyawa kimia yaitu flavonoid dan mineral. Penurunan kadar asam urat dilaporkan oleh Devina dari hasil penelitiannya secara in-vitro dengan penambahan ekstrak buah naga 3,5 g/dL atau pada dosis $35 \mathrm{mg} / \mathrm{kgBB}^{(15)}$.

Tujuan dari penelitian ini adalah untuk mengetahui efektivitas ekstrak etanol buah naga putih secara in-vivo dalam menurunkan kadar asam urat darah pada mencit yang diinduksi kafein secara oral dengan dosis $15,6 \mathrm{mg} / \mathrm{kgBB}$.

\section{BAHAN DAN METODE}

BAHAN. Bahan uji yang digunakan dalam penelitian ini adalah daging buah naga putih segar (Hylocereus undatus (Haw.) Britton \& Rose) suku Cactaceae,yang diambil dari Taman Buah Mekar Sari Cileungsi Jonggol, Bogor. Buah naga putih diambil saat berumur 50-55 hari setelah muncul bunga dengan warna kulit buah hijau kemerahan. Bahan uji dibuat 3 variasi dosis ekstrak buah naga putih dengan dosis $18,2 \mathrm{mg} /$

Tabel 1. Perlakuan terhadap kelompok hewan uji (mencit) yang diinduksi dengan kafein $15,6 \mathrm{mg} / \mathrm{kgBB}$ dalam larutan Na-CMC 0,5\%.

\begin{tabular}{ccc}
\hline Kelompok & Jumlah mencit & Perlakuan \\
\hline I & 5 & Kontrol negatif \\
II & 5 & Kontrol positif, \\
Allopurinol $10,4 \mathrm{mg} / \mathrm{kgBB}$ \\
III & 5 & Ekstrak uji $18,2 \mathrm{mg} / \mathrm{kgBB}$ \\
IV & 5 & Ekstrak uji $36,4 \mathrm{mg} / \mathrm{kgBB}$ \\
V & 5 & Ekstrak uji $72,8 \mathrm{mg} / \mathrm{kgBB}$ \\
\hline
\end{tabular}


$\mathrm{kgBB} ; 36,4 \mathrm{mg} / \mathrm{kgBB}$; dan $72,8 \mathrm{mg} / \mathrm{kgBB}$ mencit. Data pembagian kelompok dan perlakuan dapat dilihat pada Tabel 1.

Kontrol positif allopurinol diberikan $10,4 \mathrm{mg} / \mathrm{kgBB}$ mencit. Dosis ini didapatkan berdasarkan dosis efektif oral pada manusia yang dikonversikan ke dosis mencit. Pemberian bahan uji dilakukan satu kali sehari peroral dengan menggunakan jarum gavage lambung.

Hewan Uji. Hewan uji yang digunakan dalam penelitian ini adalah 25 ekor mencit jantan (Mus musculus) galur Wistar umur 4 minggu dengan berat rata-rata 25 gram diperoleh dari Institut Pertanian Bogor.

METODE. Pembuatan Ekstrak. Ekstrak buah naga dibuat dengan cara maserasi. Daging buah naga putih segar sebanyak $500 \mathrm{~g}$ diblender, kemudian dikeringkan dengan freeze dryer (Millrock) selama 6 hari. Serbuk kering buah naga ditambahkan pelarut etanol $70 \%$, dimasukan ke dalam wadah, ditutup dan dibiarkan selama dua hari terlindung dari cahaya sambil diaduk, dan setelah itu disaring. Ampasnya dimaserasi lagi dengan etanol $70 \%$ hingga diperoleh maserat yang jernih. Semua maserat etanol diuapkan dengan menggunakan alat penguap rotary evaporator (Buchi) pada temperatur $\pm 40{ }^{\circ} \mathrm{C}$ sampai diperoleh ekstrak etanol kental ${ }^{(16)}$.

Penapisan Fitokimia. Penapisan fitokimia dilakukan terhadap golongan alkaloid, flavonoid, tannin, kuinon, steroid/triterpenoid berdasarkan Materia Medika Indonesia (1995) ${ }^{(16)}$ dan Harborne $(1998)^{(17)}$.

Pemeriksaan Bebas Etanol dalam Ekstrak Buah Naga Putih. Untuk pemeriksaan bebas etanol dalam ekstrak buah naga putih dilakukan dengan cara ekstrak sebanyak 1 gram ditambahkan $\mathrm{NaOH} 1 \mathrm{~N}$ sebanyak $1 \mathrm{~mL}$ perlahan-lahan setelah itu didiamkan selama 3 menit, kemudian tambahkan secara perlahan iodium $0,1 \mathrm{~N}$ sebanyak $2 \mathrm{~mL}^{(18)}$.

Kadar Air. Ekstrak etanol 70\% buah naga putih sejumlah lebih kurang $5 \mathrm{~g}$ ditimbang seksama dalam botol timbang bertutup dan dikeringkan selama 30 menit pada suhu $105{ }^{\circ} \mathrm{C}$. Ekstrak dimasukkan kedalam botol timbang tersebut, kemudian ekstrak diratakan dalam botol timbang dengan menggoyangkan botol sehingga ekstrak menjadi rata, kemudian dimasukkan kedalam oven dengan keadaan dibuka tutupnya. Ekstrak etanol buah naga putih dipanaskan pada suhu $105^{\circ} \mathrm{C}$ selama 5 jam. Pada saat oven dibuka, botol segera ditutup dan dibiarkan dalam desikator sampai suhunya mencapai suhu ruangan sebelum ditimbang ${ }^{(19)}$.

Uji Efektivitas. Uji efektivitas ekstrak etanol 70\% buah naga putih (Hylocereus undatus (Haw.) Britton \& Rose) dilakukan secara in-vivo terhadap penurunan kadar asam urat pada darah mencit (Mus musculus) dimana kadar asam urat mencit dinaikkan dengan menggunakan kafein yang merupakan komponen alkaloid derivat xantin yang mengandung gugus metil yang akan dioksidasi membentuk asam urat sehingga dapat meningkatkan kadar asam urat dalam darah ${ }^{(20)}$. Sebagai kontrol negatif digunakan Na-CMC karena tidak mempunyai pengaruh terhadap hewan uji dan tidak memiliki efek terhadap asam urat. Selanjutnya pemeriksaan kadar asam urat pada darah mencit dilakukan menggunakan metode tes strip asam urat.

Hewan uji sebanyak 25 ekor mencit jantan galur Wistar diaklimatisasi dalam ruang percobaan selama \pm 2 minggu diberi pakan pellet dan air minum sesuai kebutuhan. Hewan uji dibagi menjadi 5 kelompok secara acak, masing-masing 5 ekor mencit yang terdiri dari kontrol positif, kontrol negatif dan tiga variasi dosis ekstrak buah naga, dapat dilihat pada Tabel 1. Kelompok kontrol positif dan negatif digunakan untuk membandingkan nilai signifikansi dari setiap kelompok hewan uji. Kontrol positif diberikan allopurinol yang telah terbukti khasiatnya dapat menurunkan kadar asam urat darah.

Pada uji efektivitas, sebelum perlakuan mencit diukur kadar asam urat darahnya untuk meyakinkan mencit yang digunakan dalam keadaan normal dan tidak hiperurisemia. Selanjutnya, pada hari pertama, mencit diinduksi dengan kafein $15,6 \mathrm{mg} / \mathrm{kgBB}$ selama enam hari berturut-turut sebelum perlakuan. Kadar asam urat darah mencit dikontrol dan diukur pada hari ke-6 untuk meyakinkan bahwa kafein dengan dosis tersebut menyebabkan kondisi mencit hiperurisemia, kemudian semua mencit diistirahatkan di dalam kandang masing-masing dan diberi makan dan minum. Pada hari ke-7 dilakukan pemberian perlakuan berdasarkan kelompoknya masing-masing setiap hari selama 9 hari percobaan. Pengukuran kadar asam urat darah dilakukan pada hari ke 0 , ke 6 (sebelum perlakuan), hari ke-9, ke-12 dan ke-15 (setelah pemberian sampel uji). Pemberian sampel uji dilakukan satu kali per hari secara oral dengan menggunakan jarum gavage lambung.

Prosedur Pengambilan Darah. Sebelum pengambilan darah, mencit dimasukkan kedalam kandang kecil sedemikian rupa hingga tidak dapat bergerak. Kemudian ekor mencit dibersihkan dengan alkohol $70 \%$. Selanjutnya ujung ekor mencit digunting kurang lebih $0,2 \mathrm{~cm}$ dari ujung ekor, dilakukan pemijatan perlahan terhadap ekor agar darah keluar.

Pengukuran Kadar Asam Urat Darah. Pengukuran kadar asam urat darah dilakukan dengan menggunakan alat tes strip asam urat. Alat tes strip Multicheck Unesco dirancang untuk pengukuran kuantitatif dari tingkat asam urat dalam darah. 
Pengukuran ini berdasarkan penentuan perubahan arus yang disebabkan oleh reaksi asam urat dengan reagen pada elektroda dari strip tersebut. Ketika sampel darah menyentuh area target sampel strip, darah secara otomatis ditarik ke dalam zona reaksi dari strip. Hasil tes akan tampil pada layar setelah 20 detik.

Perhitungan presentase penurunan kadar asam urat darah:

Penurunan $=\frac{\text { Kadar pada saat Hiperurisemia }- \text { Kadar sampel }(\text { Hari })}{\text { Kadar pada saat Hiperurisemia }- \text { Kadar Normal }} x 100 \%$

Uji Statistik Kadar Asam Urat Darah. Metode statistika yang digunakan adalah uji ANOVA satu arah terhadap kadar asam urat darah. Sebelum dilakukan uji ANOVA terlebih dahulu dilakukan uji normalitas (One-Sample Kolmogorov-Smirnov Test) dan uji Homogenitas. Pengujian tersebut merupakan hal yang lazim dilakukan sebelum sebuah metode statistika diterapkan. Berdasarkan uji normalitas (One-Sample Kolmogorov-Smirnov Test) menunjukkan kadar asam urat darah sebelum dan sesudah percobaan terdistribusi normal $(p \geq 0,05)$ dan pada uji homogenitas menunjukkan bervariasi homogen $(p \geq 0,05)$ sehingga dapat dilanjutkan dengan analisis uji ANOVA. Pada uji ANOVA satu arah bila $(\mathrm{p} \leq 0,05)$ maka harus dilakukan uji Beda Nyata Terkecil (BNT) dengan metode LSD.

\section{HASIL DAN PEMBAHASAN}

Hasil maserasi. Hasil maserasi serbuk kering buah naga diperoleh ekstrak sebanyak 21,3 g sehingga diperoleh rendemen ekstrak sebesar 14,2\%. Kadar air ekstrak etanol didapatkan 1,83\%. Penapisan fitokimia mendapatkan bahwa ekstrak buah naga putih mengandung flavonoid tetapi tidak mengandung alkaloid, saponin, tannin dan steroid/ triterpenoid. Ekstrak etanol buah naga putih telah memenuhi persyaratan organoleptik Monografi Ekstrak Tumbuhan Obat Indonesia ${ }^{(21)}$.

Hasil pemeriksaan bebas etanol dalam ekstrak buah naga putih ditunjukkan dengan tidak adanya bau iodium dan tidak adanya endapan kuning di dasar tabung sehingga menunjukkan tidak adanya lagi etanol dalam ekstrak ${ }^{(21)}$. Hasil menunjukan bahwa ekstrak sudah tidak mengandung etanol lagi.

Hasil Uji Efektivitas. Hasil uji pada hari pertama percobaan, sebelum diinduksi dengan kafein, kadar asam urat darah mencit seluruh kelompok menunjukkan hasil yang normal antara $2,26 \mathrm{mg} / \mathrm{dL}$ $-2,4 \mathrm{mg} / \mathrm{dL}$. Pada hari ke 6 setelah diinduksi kafein kadar asam urat meningkat pada kondisi hiperurisemia yaitu antara 6,24-6,98 mg/dL (Tabel 2).

Mulai pada hari ke-7 dilakukan pemberian ekstrak buah naga berdasarkan kelompoknya masing-masing setiap hari, selanjutnya pengukuran kadar asam urat darah dilakukan pada hari ke-9, ke-12 dan ke-15. Pada hari ke-9 sudah mulai terjadi penurunan kadar asam urat darah pada semua kelompok kecuali kontrol negatif dan setelah dilakukan uji BNT hari ke-9 kadar asam urat seluruh kelompok hewan uji ekstrak dan kontrol positif menunjukkan berbeda secara bermakna $(\mathrm{p} \leq 0,05)$ dengan kontrol negatif.

Pada hari ke-12 kadar asam urat darah kelompok hewan uji ekstrak dan kontrol positif menunjukkan berbeda secara bermakna $(p \leq 0,05)$ dengan kontrol negatif. Seluruh kelompok hewan uji yang diberi ekstrak buah naga menunjukkan perbedaannya tidak bermakna $(p \geq 0,05)$ dengan kontrol positif yang diberi allopurinol sehingga dapat dinyatakan walaupun seluruh kelompok hewan uji ekstrak dan kontrol pembanding kadar asam urat darahnya belum normal tetapi telah menunjukkan adanya penurunan kadar

Tabel 2. Rata-rata kadar asam urat darah mencit (mg/dL) yang diberi perlakuan kontrol negatif, kontrol positif dan ekstrak buah naga.

\begin{tabular}{|c|c|c|c|c|c|c|}
\hline \multirow[b]{2}{*}{ Perlakuan } & \multirow[b]{2}{*}{ Waktu (Hari) ke } & \multicolumn{5}{|c|}{ Kadar asam urat darah mencit (mg/dL) } \\
\hline & & Kontrol negatif & $\begin{array}{c}\text { Kontrol positif, } \\
\text { (allopurinol } \\
10,4 \mathrm{mg} / \mathrm{kgBB} \text { ) }\end{array}$ & $\begin{array}{c}\text { Ekstrak buah } \\
\text { naga, dosis } 18,2 \\
\text { mg/kgBB }\end{array}$ & $\begin{array}{c}\text { Ekstrak buah } \\
\text { naga, dosis } 36,4 \\
\mathrm{mg} / \mathrm{kgBB}\end{array}$ & $\begin{array}{c}\text { Ekstrak buah } \\
\text { naga, dosis } 72,8 \\
\mathrm{mg} / \mathrm{kgBB}\end{array}$ \\
\hline Awal & 1 & $2,26 \pm 0,13$ & $2,36 \pm 0,30$ & $2,34 \pm 0,20$ & $2,40 \pm 0,21$ & $2,34 \pm 0,18$ \\
\hline \multirow[t]{2}{*}{ Induksi Kafein } & 6 & $6,24 \pm 0,36$ & $6,98 \pm 0,86$ & $6,76 \pm 0,95$ & $6,80 \pm 0,40$ & $6,68 \pm 0,98$ \\
\hline & 9 & $6,28 \pm 0,32$ & $6,08 \pm 0,52 *$ & $5,68 \pm 0,56^{*}$ & $6,40 \pm 0,97^{*}$ & $6,20 \pm 0,94^{*}$ \\
\hline \multirow[t]{2}{*}{$\begin{array}{l}\text { Diberi } \\
\text { perlakuan }\end{array}$} & 12 & $6,38 \pm 0,41$ & $4,80 \pm 0,61^{*}$ & $5,26 \pm 0,45^{*}$ & $5,36 \pm 0,76^{*}$ & $5,12 \pm 0,99^{*}$ \\
\hline & 15 & $6,48 \pm 0,36$ & $2,42 \pm 0,08^{*}$ & $4,94 \pm 0,42 *$ & $3,94 \pm 0,56^{*}$ & $2,68 \pm 0,19 *$ \\
\hline
\end{tabular}

Keterangan: * = hari ke 9, ke 12 dan ke 15, kontrol negatif berbeda nyata dengan semua dosis perlakuan $(p \leq 0,05)$. 


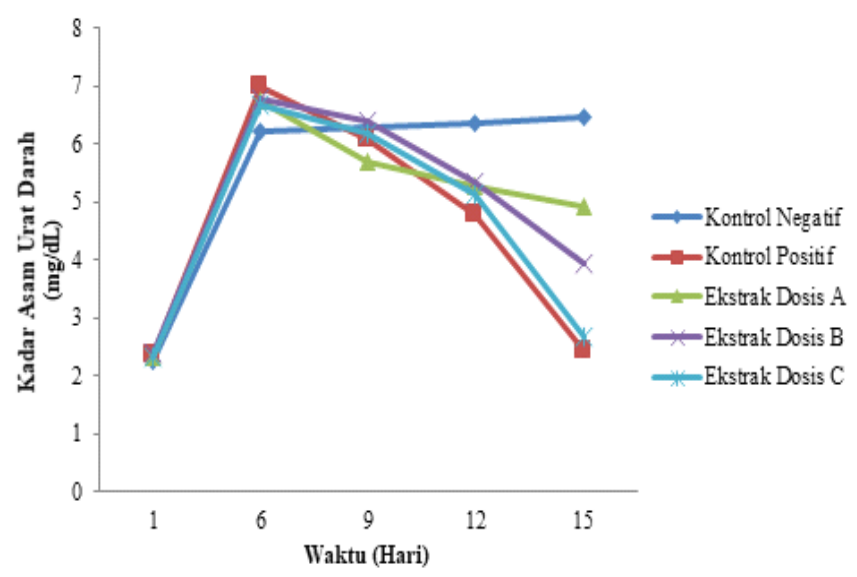

Gambar 1. Kurva kadar asam urat darah (mg/dL) rata-rata hewan uji mencit selama percobaan, yang diinduksi dengan kafein 15,6 mg/kgBB pada hari pertama, dan pada hari ke 7 sampai hari ke 15 diberi perlakuan dengan dosis A 18,2 mg/kgBB, dosis B36,4 mg/kgBB, dosis C 72,8 mg/kgBB pada sampel uji, kontrol positif diberi allopurinol 10,4 mg/kgBB, dan kontrol negatif tanpa penambahan apapun.

asam urat dibandingkan dengan kontrol negatif dan kerja semua ekstrak uji sebanding dengan kontrol positif (Gambar 1).

Data efektivitas penurunan kadar asam urat rata -rata pada hari ke-15 yang diperoleh dari setiap kelompok terlihat bahwa allopurinol (kontrol positif) memiliki kemampuan menurunkan kadar asam urat darah yang paling besar yaitu $98,72 \%$. Efektivitas kedua yang dimiliki oleh kelompok ekstrak uji dosis $72,8 \mathrm{mg} / \mathrm{kgBB}$ yaitu $92,16 \%$, dosis $36,4 \mathrm{mg} / \mathrm{kgBB}$ yaitu $65,0 \%$ dan kelompok dosis $18,2 \mathrm{mg} / \mathrm{kgBB}$ yaitu sebesar 41,17\% (Tabel 3, Gambar 1).

Tabel 3. Presentase penurunan kadar asam urat darah ratarata kelompok kontrol pembanding dan ekstrak uji pada hari ke 9, ke 12 dan ke 15 setelah perlakuan.

\begin{tabular}{|c|c|c|c|}
\hline \multirow{2}{*}{ Kelompok perlakuan } & \multicolumn{3}{|c|}{$\begin{array}{c}\text { Penurunan kadar asam urat (\%) } \\
\text { pada hari ke: }\end{array}$} \\
\hline & 9 & 12 & 15 \\
\hline Kontrol Positif & 19,48 & 46,98 & 98,72 \\
\hline Dosis $18,2 \mathrm{mg} / \mathrm{kgBB}$ & 9,04 & 24,43 & 41,17 \\
\hline Dosis $36,4 \mathrm{mg} / \mathrm{kgBB}$ & 9,09 & 32,72 & 65,00 \\
\hline Dosis $72,8 \mathrm{mg} / \mathrm{kgBB}$ & 11,05 & 35,94 & 92,16 \\
\hline
\end{tabular}

Pada hari ke-15 kadar asam urat seluruh kelompok ekstrak uji dan kontrol positif menunjukkan berbeda secara bermakna $(\mathrm{p} \leq 0,05)$ dengan kontrol negatif; ekstrak uji dosis $72,8 \mathrm{mg} / \mathrm{kgBB}$ menunjukkan tidak berbeda nyata $(\mathrm{p} \geq 0,05)$ dengan kontrol positif yang berarti efek yang dihasilkan oleh ekstrak uji adalah sama dengan kontrol positif yang diberi allopurinol.

Hasil analisa statistik yang membandingkan antara masing-masing dosis ekstrak etanol buah naga putih menunjukkan perbedaan yang nyata. Itu artinya masing-masing dosis mempunyai kemampuan menurunkan kadar asam urat darah yang berbeda dimana semakin tinggi dosisnya, daya penurunannya juga semakin meningkat.

Ekstrak etanol buah naga putih dapat menurunkan kadar asam urat darah sesuai dengan penelitian karena adanya kandungan flavonoid dalam buah naga putih tersebut. Hasil penelitian ini memperkuat hasil yang telah pernah dilakukan oleh Devina, dengan penambahan ekstrak buah naga pada sejumlah tertentu asam urat secara in-vitro dapat menurunkan kadar asam urat. Flavonoid merupakan antioksidan yang berkerja dengan menghambat kerja enzim xanthin oksidase sehingga produksi asam uratpun dapat berkurang ${ }^{(2)}$.

Belum banyak publikasi penelitian tentang efek dari buah naga terhadap kondisi hiperurisemia. Hasil yang sudah banyak diteliti dan dilakukan uji metaanalisis adalah efek dari buah naga terhadap kecenderungan penurunan kadar glukosa darah pada prediabetes, sebagai upaya prefentif ${ }^{(19)}$. Kandungan kimia dari buah naga yang kaya antioksidan alam, termasuk betacyanin, flavonoid, asam fenolik, vitamin C. dengan uji klinik terbukti memiliki efek anti-diabetes dengan regenerasi sel pankreas- $\beta$ dan melemahkan fibroblast growth factor-21 (FGF-21) resistensi ${ }^{(22,23)}$.

\section{SIMPULAN}

Dari hasil penelitian menunjukan bahwa ekstrak etanol $70 \%$ buah naga putih dosis $72,8 \mathrm{mg} / \mathrm{kgBB}$ 
dapat menurunkan kadar asam urat darah pada mencit di hari ke 15 dengan presentase penurunan sebesar $92,16 \%$. Angka tersebut berbeda nyata dibandingkan dosis $36,4 \mathrm{mg} / \mathrm{kgBB}$ dan $18,2 \mathrm{mg} / \mathrm{kgBB}$, tetapi tidak berbeda dengan kontrol positif (allopurinol). Jadi ekstrak dosis $72,8 \mathrm{mg} / \mathrm{kgBB}$ sama efeknya terhadap mencit dengan pemberian allopurinol $10,4 \mathrm{mg} / \mathrm{kgBB}$. Hasil penelitian ini memperlihatkan adanya potensi dari ekstrak etanol 70\% buah naga putih (Hylocereus undatus) untuk menurunkan kadar asam urat darah pada kondisi hiperuresemia. Penelitian lebih lanjut dapat disarankan untuk isolasi, identifikasi komponen bioaktif buah naga putih yang berperan dalam menurunkan kadar asam urat didalam darah serta uji klinik terhadap pasien hiperurisemia.

\section{UCAPAN TERIMA KASIH}

Ucapan terima kasih kepada para staf laboratorium kimia Program Studi Farmasi Fakultas Farmasi ISTN, atas bantuannya dalam pelaksanaan kegiatan penelitian ini.

\section{DAFTAR PUSTAKA}

1. Saag KG, Choi H. Epidemiology, risk factors and lifestyle modifications for gout. Arthrit Res \& Ther. 2006.8(1):1-7: diambil dari https://www.ncbi.nlm. nih.gov/pubmed/16820041 diakses 26 Agustus 2018.

2. Richette P, Bardin T. Gout. The Lancet. 2010. 375:318-28: diambil dari doi:10.1016/s01406736(09)60883-7, diakses 26 Agustus, 2018

3. Dalimartha S. Resep tumbuhan obat untuk asam urat. Jakarta: Penebar Swadaya; 2011. p. 5, 7, 12, 58.

4. Neogi T, Jansen TLTA, Dalbeth N, Fransen J, Schumacher HR, Berendsen D, et al. Gout classification criteria: An american college of rheumatology/ european league against rheumatism collaborative initiative. J Arthritis and Rheumat. 2015.67(10): 255768.

5. Shaefer MS and Pierre AM. Clinical pharmacy and theraupetics. $5^{\text {th }}$ edition. Maryland: William \&Wilkins; 1992.507-18.

6. Kementerian Kesehatan RI. Hasil riset kesehatan dasar tahun 2013: diambil dari http://www.depkes.go.id/ resources/download/general/HasilRiskesdas2013. diakses 26 Agustus 2018.

7. Kuo CF, See LC, Luo SF, Ko YS, Lin YS, Hwang JS, et al. Concise report gout: an independent risk factor for all-cause and cardiovascular mortality. Rheumatology. 2010.49:141-6.

8. Puig JG, Martínez MA. Hyperuricemia, gout and the metabolic syndrome. Current Opinion in Rheumatology. 2008.20(2):187-91.

9. Astari E. Pengaruh pemberian decocta daun dewa (Gynura Pseudochina (L) Dc) terhadap penurunan kadar asam urat serum pada mencit putih jantan galur Balb-C hiperurisemia [skripsi]. Surakarta: Univ Muhammadiyah Surakarta; 2008.

10. Dalbeth N, Bardin T, Doherty M, Liote F, Richette P, Saag KG, et al. Discordant American college of physicians and international rheumatology guidelines for gout management: Consensus statement of the gout, hyperuricemia and crystal associated disease network (G-CAN). November 2016: diambil dari https://www.nature.com/articles/nrrheum.2017.126. diakses 26 Agustus 2018.

11. Chemah TC, Aminah A, Noriham A, Wan Aida WM. Determination of pitaya seeds as a natural antioxidant and source of essential fatty acids. Intern Food Res J. 2010.17:1003-10.

12. Choo WS, Yong WK. Antioxidant properties of two species of Hylocereus fruits. Adv in Appl Sci Res. 2011.2(3):418-25.

13. Jaafar RA, Rahman ARB, Mahmod NZC, Vasudevan R. Proximate analysis of dragon fruit (Hylecereus polyhizus). American J Appl Sci. 2009.6:1340-46.

14. Swastika S, dkk. Hama dan penyakit buah naga. 201: diambil dari URL: http://riau.litbang.pertanian.go.id/ ind/images/stories/PDF/naga.pdf. diakses tanggal 5 April 2016.

15. Devina IA, dkk. Mineral dalam buah naga (Hylocereus Undatus (Haw.) Britt. \& Rose) sebagai penurun asam urat secara in-vitro. J Ilmiah Kesehatan. 2013.5:26-30.

16. Departemen Kesehatan Republik Indonesia. Materia medika Indonesia. Jilid VI. Jakarta: Departemen Kesehatan Republik Indonesia; 1995.

17. Harborne JB. Phytochemical methods: a guide to modern techniques of plant analysis. $3^{\text {rd }}$ ed. Springer Netherlands. 1998.

18. BPOM RI. Monografi ekstrak tumbuhan obat Indonesia. 2004.1:15-21.

19. Departemen Kesehatan Republik Indonesia. Farmakope Indonesia Edisi IV. Jakarta: Direktorat Jenderal Pengawasan Obat dan Makanan; 1995.p. 1033-36.

20. Kusuma AM, Wahyuningrum R, Widyati T. Aktivitas antihiperurisemia ekstrak etanol herba pegagan pada mencit jantan dengan induksi kafein. Pharmacy. 2014. 11(01): 62-74.

21. Departemen Kesehatan Republik Indonesia. Farmakope Indonesia Edisi III. Jakarta: Departemen Kesehatan Republik Indonesia; 1979.

22. Poolsup N, Suksomboon N, Paw NJ. Effect of dragon fruit on glycemic control in prediabetes and type 2 diabetes: A systematic review and meta-analysis. PLoS ONE. [serial online]. September 2017.12(9): e0184577: diambil dari https://doi.org/10.1371/ journal.pone.0184577 diakses 9 Agustus 2018.

23. Song H, Chu Q, Xu D, Xu Y, Zheng X. Purified betacyanins from Hylocereus undatus peel ameliorate obesity and insulin resistance in high-fat-diet-fed mice. J Agric Food Chem. 2015.64(1):236-44. 